\title{
Geochronologic evidence for Early Cretaceous volcanic activity on Barton Peninsula, King George Island,
} Antarctica

\author{
Hyeoncheol Kim, Jong Ik Lee, Moon Young Choe, \\ Moonsup Cho, Xiangshen Zheng, Haiqing Sang \& \\ Ji Qiu
}

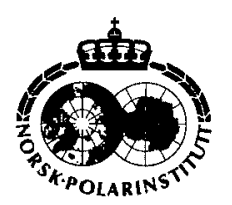

Ages of six volcanic and plutonic rocks on Barton Peninsula, King George Island, were determined using ${ }^{40} \mathrm{Ar} /{ }^{39} \mathrm{Ar}$ and $\mathrm{K}-\mathrm{Ar}$ isotopic systems. The ${ }^{40} \mathrm{Ar} /{ }^{39} \mathrm{Ar}$ and $\mathrm{K}$-Ar ages of basaltic andesite and diorite range from $48 \mathrm{My}$ to $74 \mathrm{My}$ and systematically decrease toward the upper stratigraphic section. Two specimens of basaltic andesite which occur in the lowermost sequence of the peninsula, however, apparently define two distinct plateau ages of 52-53 My and 119-120 My. The latter is interpreted to represent the primary cooling age of basaltic andesite, whereas the former is interpreted as the thermally-reset age caused by the intrusion of Tertiary granitic pluton. The isochron ages calculated from the isotope correlation diagram corroborate our interpretation based on the apparent plateau ages. It is therefore likely that volcanism was active during the Early Cretaceous on Barton Peninsula. When the K-Ar ages of previous studies are taken into account with our result, the ages of basaltic andesite in the northern part of the Barton Peninsula are significantly older than those in the southern part. Across the north-westsouth-east trending Barton fault bounding the two parts, there are significant differences in geochronologic and geologic aspects.

H. Kim, Isotope Research Team, Korea Basic Science Institute, Yeo-Eun Dong 52, Yusung-Ku, Taejon 305-333, South Korea; J. I. Lee \& M. Y. Choe. Polar Science Laboratory, Korea Ocean Research \& Development Institute, Sa-dong 1270, Ansan 425-170. South Korea; M. Cho, Dept. of Geological Sciences, Seoul National University, Seoul 151-742, South Korea; X. Zheng, H. Sang \& J. Qiu, Institute of Geology. Chinese Academy of Sciences, Beijing 100029, China.

The South Shetland Islands, situated along the Pacific margin of the Antarctic Peninsula (Fig. 1), represent a magmatic arc of Jurassic to Quaternary age. Volcanic sequences and plutonic intrusions in these islands built upon a pre-volcanic, sialic basement of pre-Jurassic schists and deformed sedimentary rocks. The latter is primarily composed of late Palaeozoic-early Mesozoic turbiditic submarine fan deposits (Smellie, Liesa et al. 1995). Marine sedimentary rocks containing Late Jurassic-Early Cretaceous fossil faunas are succeeded by terrestrial volcanic sandstones and conglomerates, then by basalt to dacite lavas interbedded with andesitic and rhyolitic ignimbrites (Smellie, Pankhurst et al. 1984; Arche et al. 1992; Willan et al. 1994; Smellie, Liesa et al. 1995; Hathway \& Lomas 1998).

King George Island is the largest island in the South Shetland Islands and mainly consists of volcanic and plutonic rocks of calc-alkaline affinity. Petrography and geochemistry of King George Island have been well documented by previous workers (Barton 1965; Birkenmajer 


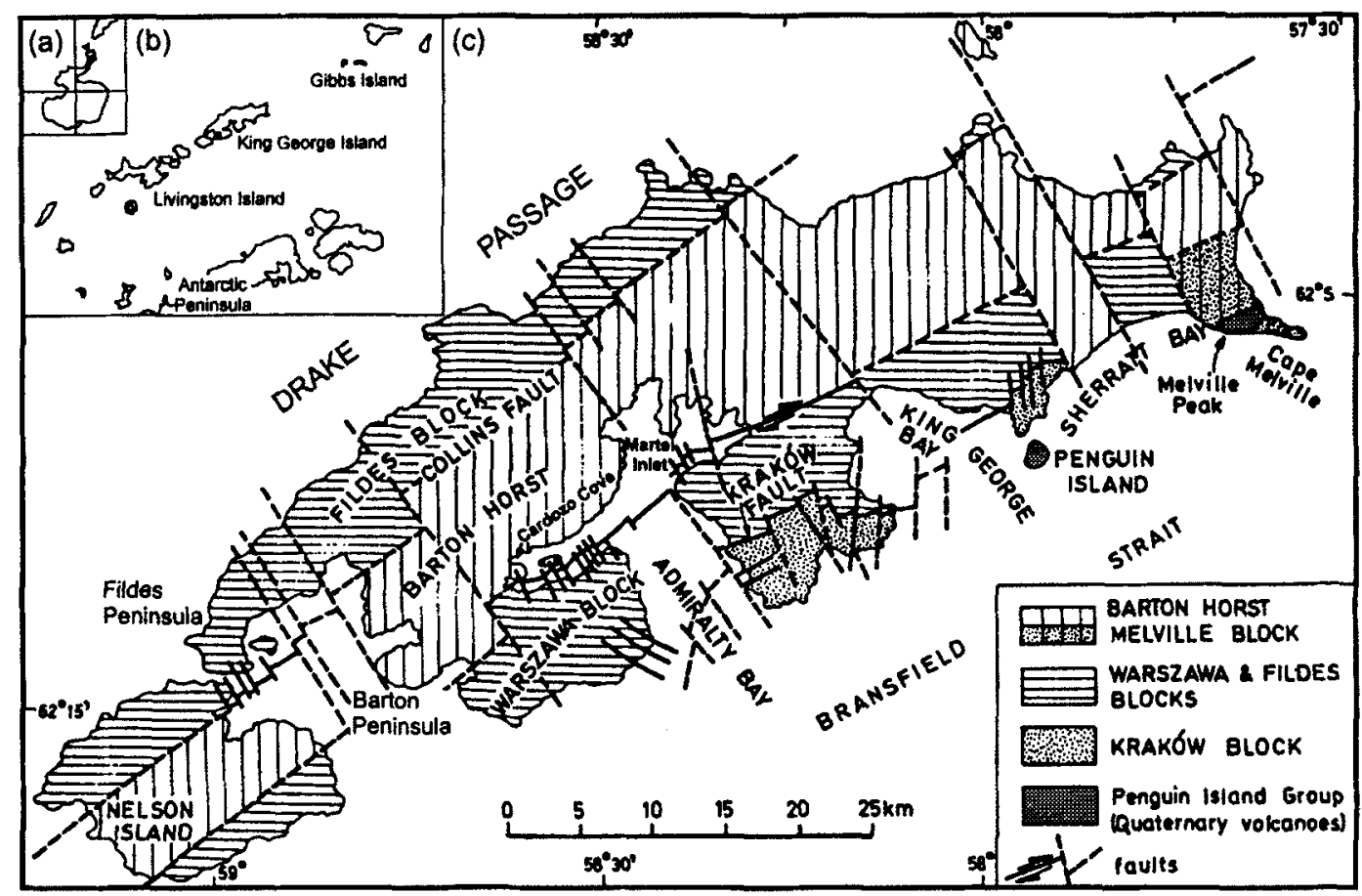

Fig. 1. Structural elements of King George and Nelson islands (after Birkenmajer 1983).

1983: Smellie, Pankhurst et al. 1984: Tokarski 1988; Kang \& Jin 1989; Lee et al. 1996).

Ferguson (1921) has classified the stratiform volcanic complexes of King George Island into an older and a younger series, based on the observation that the Andean intrusive suite intrudes the older series but never the younger series. The older series was tentatively correlated with Jurassic rocks of Graham Land, whereas the younger series with Cenozoic rocks (Tyrrell 1921). The temporal gap in these volcanic complexes was confirmed by Birkenmajer (1980a-d): Cardozo Cove and Martel Inlet Groups at Admiralty Bay (Fig. 1c), predating the Andean intrusions, are correlated with the older series of Ferguson (1921), whereas the King George Island Supergroup correlates with the younger series. Furthermore, based on lithology and stratigraphy, Birkenmajer (1983) divided King George Island into three tectonic blocks bounded by strike-slip faults (Fig. lc). The Andean intrusives are restricted to the central block, or the so-called "backbone", corresponding to the upthrown Barton Horst to which Barton Peninsula belongs (Birkenmajer, Francalanci et al. 1991).

Birkenmajer (1983) and Kang \& Jin (1989) reported Palaeocene $\mathrm{K}-\mathrm{Ar}$ whole rock and $\mathrm{Rb}-\mathrm{Sr}$ biotite ages (60-63 My) for mafic plutonic rocks. Recent geochronologic data from Barton Peninsula, however, suggest Eocene volcanic and plutonic activity (Park 1989; Lee et al. 1996). K-Ar wholerock ages of volcanic rocks range from 35.5 to $48.5 \mathrm{My}$, whereas those of plutonic rocks mostly from 42.1 to $45.2 \mathrm{My}$ (Park 1989). K-Ar biotite ages of plutonic rocks are in the range of 41.241.9 My (Lee et al. 1996). Because of intrinsic problems, such as the Ar loss in K-Ar isotopic ages, further discussion on the apparent discrepancy is not warranted.

In this paper, we present ${ }^{40} \mathrm{Ar} /{ }^{39} \mathrm{Ar}$ as well as $\mathrm{K}$ Ar ages of volcanic and intrusive rocks on Barton Peninsula, King George Island. ${ }^{40} \mathrm{Ar} /{ }^{39} \mathrm{Ar}$ ages provided us with new geochronologic constraints not only for Cretaceous volcanic activity on King George Island but also the temporal relationship of volcanism in the South Shetland Islands.

\section{Geological setting and sample description}

Barton Peninsula is composed of volcanic and 
Fig. 2. Geologic map of Barton and Weaver peninsulas, King George Island, Antarctica.

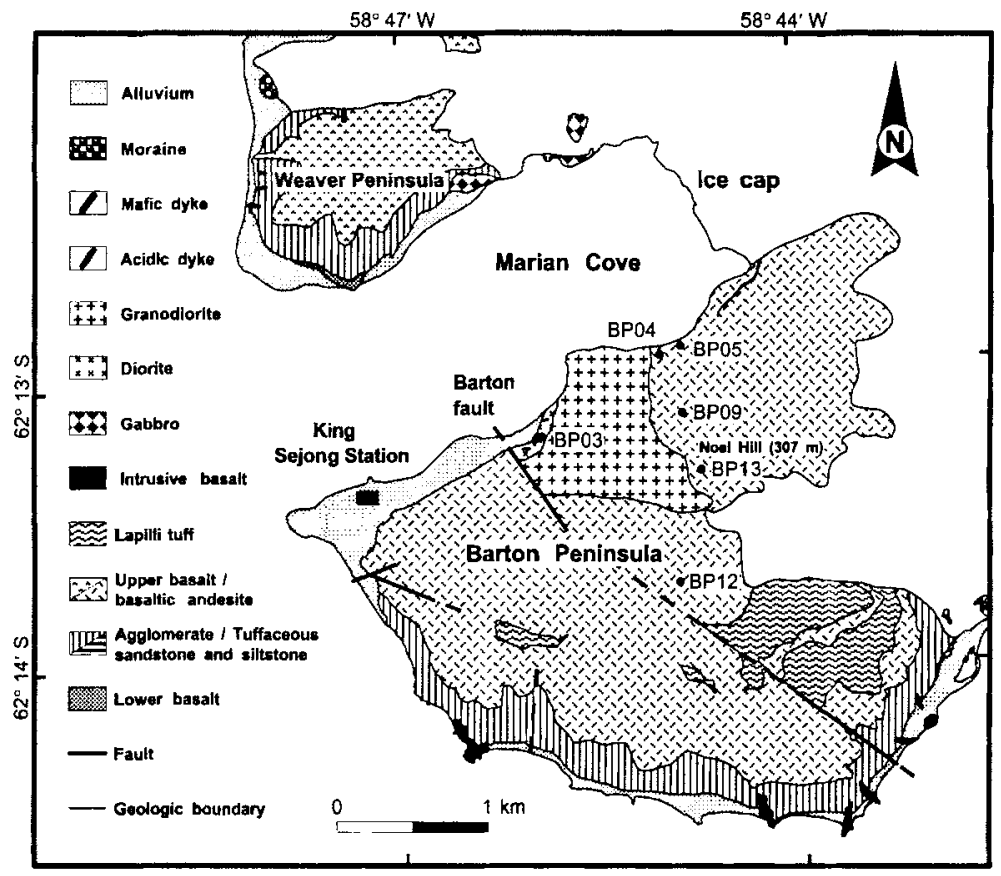

plutonic rocks together with minor thin-bedded sandstone and siltstone (Fig. 2). Volcanic rocks in the peninsula mainly consist of basalt, basaltic andesite, agglomerate and lapilli tuff, whereas plutonic rocks include granodiorite and diorite. Acidic dykes are common in diorite. Fine-grained diorite, corresponding to the lower part of granitic pluton, consists of plagioclase, clinopyroxene, hornblende, biotite and $\mathrm{Fe}$ - Ti oxides with minor quartz. Medium-grained granodiorite, representing a main body of the pluton, is composed of plagioclase, quartz, alkali feldspar, hornblende, biotite and Fe-Ti oxides. The ubiquitous occurrence of miarolitic cavities indicates that this pluton was emplaced at a shallow level in the upper crust. Petrological and geochemical studies by Lee et al. (1996) further suggest that the plutonic rocks are vertically zoned. The pluton is bounded to the south-west by the north-westsouth-east trending Barton fault, which apparently penetrates the whole peninsula.

Stratification of volcanic rocks is well-preserved to the north of the pluton along the sea cliff. Bedding planes of the volcanic sequences generally strike north-east or north-west and consistently dip south at $10-40^{\circ} \mathrm{NE}$ or NW (Kang \& Jin 1989). The lapilli tuff mainly occurs to the north of the Barton fault and locally to the south.
The agglomerate occurs as a ca. $10 \mathrm{~m}$ thick layer along the southern coast of the peninsula. Both agglomerate and lapilli tuff contain a variety of volcanic glasses and breccias, but lithic fragments of crystalline rocks are absent.

Basaltic andesites overlain by the lapilli tuff are widespread in the peninsula and generally porphyritic in texture. Phenocrysts consist primarily of plagioclase together with minor clinopyroxene and orthopyroxene. Holocrystalline groundmass of basaltic andesite commonly shows flow textures defined by the preferred orientation of plagioclase microlites.

Volcanic rocks on Barton Peninsula are affected by hydrothermal alteration (So et al. 1995) and low-temperature thermal metamorphism (Kim et al. 1995). Kim et al. (1995) defined two metamorphic zones, changing from a calcite-chlorite zone to a amphibole-chlorite zone toward the pluton on the peninsula. Mineral assemblages of metavolcanics are represented by epidote + chlorite \pm hornblende \pm actinolite \pm calcite $(+$ plagioclase, quartz, opaque minerals), suggesting the greenschist to lower-amphibolite facies metamorphism. Further details on thermal metamorphism will be reported elsewhere (Kim et al. 2000).

We have analysed three basaltic andesites and one diorite for the ${ }^{40} \mathrm{Ar} /{ }^{39} \mathrm{Ar}$ age determination and 
two basaltic andesites for the K-Ar age determination. All samples were collected from the northern part of the Barton fault. Fresh samples were chosen to minimize the effect of argon loss or contamination, but most of these samples contained small amounts of secondary minerals such as chlorite and white mica. In addition, all of amphibole crystals of diorite are altered completely to actinolite.

\section{Analytical procedure}

\section{${ }^{* 0} \mathrm{Ar}{ }^{39} \mathrm{Ar}$ method}

The analysis for ${ }^{40} \mathrm{Ar} /{ }^{39} \mathrm{Ar}$ age determination was carried out at the Institute of Geology, Chinese Academy of Sciences, following the procedures described by Hu, Wang et al. (1985). The samples were ground into sizes of 60-80 mesh and packaged in aluminum foil together with the flux monitors. The flux monitors include ZBJ hornblende (132.8 $\pm 3.1 \mathrm{Mya}), \mathrm{ZBH}-25$ biotite $(132.7 \pm 2.8 \mathrm{Mya})$ and international standard sample, BSP-1 hornblende $(2060 \pm 18$ Mya). Both samples and flux monitors were evacuated and sealed hermetically in quartz ampoules. $\mathrm{K}_{2} \mathrm{SO}_{4}$ and $\mathrm{CaF}_{2}$ were added into each package to monitor the interfering reactions ${ }^{40} \mathrm{~K}(\mathrm{n}, \mathrm{p})^{40} \mathrm{Ar}$, ${ }^{41} \mathrm{~K}(\mathrm{n}, \alpha){ }^{40} \mathrm{Ar},{ }^{40} \mathrm{Ca}(\mathrm{n}, \alpha){ }^{37} \mathrm{Ar},{ }^{40} \mathrm{Ca}(\mathrm{n}, \mathrm{n} \alpha){ }^{36} \mathrm{Ar}$ and ${ }^{42} \mathrm{Ca}(\mathrm{n}, \alpha){ }^{39} \mathrm{Ar}$. Then, two basaltic andesite (BP05 and $\mathrm{BP} 13$ ) samples and one diorite (BP03) sample were put in the B4 channel of 49-2 Reactor for 4320 minutes and irradiated with fast neutron flux $\left(0.56 \times 10^{13} \mathrm{n} / \mathrm{cm}^{2} \mathrm{sec}\right)$. The total amount of the integrated fast neutron flux is $1.45 \times 10^{18} \mathrm{n} / \mathrm{cm}^{2}$. On the other hand, one basaltic andesite sample (BP04) was placed in the B8 channel of 49-2 Reactor for 3174 minutes and irradiated with instantaneous fast neutron flux $\left(4.22 \times 10^{1.3} \mathrm{n} /\right.$ $\mathrm{cm}^{2} \mathrm{sec}$ ) and the total amount of the integrated fast neutron flux is $8.04 \times 10^{18} \mathrm{n} / \mathrm{cm}^{2}$. A $0.5 \mathrm{~mm}$ thick cadmium foil was used as a shield to prevent the interference of slow neutrons. During the irradiation, the sample box was cooled by water, $42^{\circ} \mathrm{C}$ at the outlet, and was rotated 2 to 8 times per minute to eliminate a transverse gradient of neutron flux.

After cooling to a safe dosage, the irradiated samples were put in an Ar-extraction system to carry out step heating analysis. A high frequency oven was used to heat the samples at each step for 20 minutes. The extracted argon was purified by
$\mathrm{CuO}$ and sponge titanium and then introduced directly to RAG-10 mass spectrometer for argon isotope analysis. Apparent ages were corrected for mass discrimination, interference of $\mathrm{K}$ and $\mathrm{Ca}$ to $\mathrm{Ar}$ isotope, and ${ }^{37} \mathrm{Ar}$ radioactive decay. The measured correction factors for the interference of $\mathrm{K}$ and $\mathrm{Ca}$ to $\mathrm{Ar}$ isotope are $\left({ }^{40} \mathrm{Ar} /{ }^{39} \mathrm{Ar}\right)_{\mathrm{K}}$ $=3.05 \times 10^{-2},\left({ }^{36} \mathrm{Ar} r^{37} \mathrm{Ar}\right)_{\mathrm{Ca}}=2.64 \times 10^{-4}$ and $\left({ }^{39} \mathrm{Ar} r^{37} \mathrm{Ar}\right)_{\mathrm{Ca}}=6.87 \times 10^{-4}(\mathrm{Hu}$, Wang et al. 1985). A half life of 35.1 days was adopted to correct the radioactive decay of ${ }^{37} \mathrm{Ar}$. Uncertainty is quoted as one sigma and does not include that of the calculated J-factor. Isochrons were regressed following the method of York (1969).

\section{$K$-Ar method}

Quantitative analysis of argon was performed by isotopic dilution method using a ${ }^{38} \mathrm{Ar}$ spike at the Institute of Geology, Chinese Academy of Sciences. Samples were fused at $14500^{\circ} \mathrm{C}-1500^{\circ} \mathrm{C}$ for 40 minutes. $\mathrm{CuO}$ and sponge titanium were used as purifiers and ${ }^{38} \mathrm{Ar}$ spike was added during the purification process. The purified argon was directly introduced into RAG-10 mass spectrometer for isotopic analysis. Potassium concentration was measured by a flame photometer.

The decay constants and isotopic abundance ratio of $\mathrm{K}$ used in the age calculation are as follows: $\lambda=5.543 \times 10^{-10} \mathrm{y}^{-1}, \quad \lambda_{\beta}=4.962 \times$ $10^{-10} \mathrm{y}^{-1}, \quad \lambda_{\mathrm{e}}=0.581 \times 10^{-10} \mathrm{y}^{-1}, \quad{ }^{40} \mathrm{~K} / \mathrm{K}=$ 0.01167 (atomic \%) (Steiger \& Jäger 1977).

\section{Results}

The K-Ar whole-rock ages of two basaltic andesites are listed in Table 1. The K-Ar age of BP09 is older than that of BP12, which was collected from a stratigraphically upper part near the Barton fault (Fig. 2). The ${ }^{40} \mathrm{Ar} /{ }^{39} \mathrm{Ar}$ incremental heating data and ages of basaltic andesite and diorite are listed in Table 2. The results of ${ }^{40} \mathrm{Ar} /{ }^{39} \mathrm{Ar}$ whole-rock ages are shown in Fig. 3. Isotope correlation ages of basaltic andesite (BP04, BP05 and BP13) range apparently from $53 \pm 2 \mathrm{My}$ to $118 \pm 4 \mathrm{My}$, whereas that of diorite (BP03) is $48.8 \pm 1.5 \mathrm{My}$.

Specimen BP04 records an internally discordant ${ }^{40} \mathrm{Ar} /{ }^{39} \mathrm{Ar}$ age spectrum that apparently defines two "plateau" ages: $52 \pm 1$ My from low-temperature fractions (steps 2 to 4) and $119 \pm 1 \mathrm{My}$ from high-temperature fractions (steps 6 to 9) (Fig. 3a). 
Table I. K-Ar whole-rock ages of basaltic andesite.

\begin{tabular}{|c|c|c|c|c|c|c|}
\hline $\begin{array}{l}\text { Sample } \\
\text { number }\end{array}$ & $\begin{array}{c}\text { Sample } \\
\text { weight } \\
\text { (g) }\end{array}$ & $\begin{array}{c}\mathrm{K} \\
(w \mathrm{t} \%)\end{array}$ & $\begin{array}{c}{ }^{41} \mathrm{Ar} * \\
\left(10^{-10} \mathrm{~mol} / \mathrm{g}\right)\end{array}$ & $\begin{array}{c}{ }^{40} \mathrm{Ar} \text { atmosphere } \\
(\%)\end{array}$ & ${ }^{41)} \mathrm{Ar}^{*}{ }^{40} \mathrm{~K}$ & $\begin{array}{c}\text { Age } \\
( \pm 1 \sigma, \mathrm{My})\end{array}$ \\
\hline $\mathrm{BP} 09$ & 0.1764 & 0.75 & 0.98108 & 68.1 & 0.004383 & $73.9 \pm 4.4$ \\
\hline $\mathrm{BPl} 2$ & 0.2780 & 1.04 & 0.83859 & 79.8 & 0.002702 & $45.9 \pm 3.8$ \\
\hline
\end{tabular}

These plateau data define, respectively, two isochron ages in ${ }^{36} \mathrm{Ar} /{ }^{40} \mathrm{Ar}$ versus ${ }^{39} \mathrm{Ar} /{ }^{40} \mathrm{Ar}$ isotope correlation diagram (Fig. 3b). Four hightemperature steps, recording similar apparent ages, yield a plateau isotope correlation age of $118 \pm 4 \mathrm{My}$ with a ${ }^{40} \mathrm{Ar} /{ }^{36} \mathrm{Ar}$ intercept value of $290 \pm 3$. These values are indistinguishable from the plateau age and the atmospheric ratio of 295.5 , respectively. On the other hand, three or four steps at temperatures of $460^{\circ} \mathrm{C}-900^{\circ} \mathrm{C}$ yield an isochron age of $53 \pm 2 \mathrm{My}$ which is identical to the apparent "plateau" age of $52 \pm 1$ My within error range. The ${ }^{40} \mathrm{Ar} /{ }^{36} \mathrm{Ar}$ intercept value of $288 \pm 4$ is larger than the ${ }^{40} \mathrm{Ar} /{ }^{39} \mathrm{Ar}$ ratio in the present-day atmosphere, indicating the presence of minor excess ${ }^{40} \mathrm{Ar}$ in low-temperature fractions.

Specimen BP05 yield a ${ }^{40} \mathrm{Ar} /{ }^{39} \mathrm{Ar}$ apparent age spectrum with characteristics similar to those of BP04. defining two apparent "plateau" ages of $53.1 \pm 1.5 \mathrm{My}$ and $120.4 \pm 1.6 \mathrm{My}$ (Fig. 3c). These ages are consistent with the plateau ages of $\mathrm{BP} 04$. The old plateau age is based on three hightemperature steps comprising $>70 \%$ of the ${ }^{39} \mathrm{Ar}_{\mathrm{K}}$ released. Furthermore, the $\mathrm{Ca} / \mathrm{K}$ ratio of these steps (Table 2) are consistently high, suggesting the outgassing from actinolite-hornblende phenocrysts. In the isotope correlation diagram (Fig. 3d), data points of low-temperature fractions are too concentrated in a small area to define an isochron age, hightemperature steps yield a plateau isotope correlation age of $105 \pm 5.5 \mathrm{My}$. Because the isotope correlation ages do not assume any ${ }^{40} \mathrm{Ar} /{ }^{39} \mathrm{Ar}$ ratio, they are considered to be more reliable than the apparent plateau ages. Hence, the $105 \pm 5.5 \mathrm{My}$ age is geologically significant and is interpreted to be close to the formation age of basaltic andesite BP05.

Specimens BP13 and BP03 record concordant whole-rock ${ }^{40} \mathrm{Ar} /{ }^{39} \mathrm{Ar}$ apparent age spectra (Figs. $3 \mathrm{e}, \mathrm{g})$ and define the isochron ages of $60.6 \pm$ $1.4 \mathrm{My}$ and $48.8 \pm 1.5 \mathrm{My}$, respectively. which are identical to plateau age within error range (Figs. 3f. g).

When we consider the stratigraphic relationship of each sample, the $\mathrm{K}-\mathrm{Ar}$ and ${ }^{40} \mathrm{Ar} /{ }^{34} \mathrm{Ar}$ whole- rock ages of basaltic andesite decrease progressively from the stratigraphically lower part (BP04 and BP05) to the upper part (BP13) (Fig. 4). The apparent ages from low-temperature fractions of BP04 and BP05 indicate that they were partly reset by the emplacement of plutonic rocks about $49 \mathrm{Mya}(\mathrm{BP} 03)$. The ${ }^{40} \mathrm{Ar} /{ }^{39} \mathrm{Ar}$ ages from hightemperature fractions. however, indicate the presence of Cretaceous volcanic activity on Barton Peninsula. On the other hand, $\mathrm{K}-\mathrm{Ar}$ and ${ }^{40} \mathrm{Ar} /{ }^{39} \mathrm{Ar}$ ages of $\mathrm{BP} 12$ and $\mathrm{BP} 03$, respectively, are consistent with the previously reported ages (Fig. 4), suggesting an early Tertiary magmatism.

\section{Discussion and geologic implications}

Birkenmajer (1989) suggested considerable differences in stratigraphic succession, ages and characteristics of three tectonic blocks: i.e. Fildes Block, Barton Horst and Warszawa Block. Barton Horst, upthrown relative to Fildes and Warszawa blocks and more deeply eroded than the other two blocks, exposes the plutonic rocks intruding into the old volcanic strata.

Although Mesozoic volcanic activities are suggested in the Fildes Peninsula and Admiralty Bay of King George Island (Ferguson 1921; Davies 1982; Birkenmajer 1983; Birkenmajer, Narebski et al. 1983a), no Mesozoic isotope age of volcanic rocks are reported from Barton Peninsula. $\mathrm{K}-\mathrm{Ar}$ and $\mathrm{Rb}-\mathrm{Sr}$ ages of volcanic rocks in the Barton Horst apparently range from Paleocene to Eocene (Birkenmajer, Narebski et al. 1983a, b; Kawashita \& Soliani 1988; Park 1989). The K-Ar ages of volcanic specimens collected from the southern part of the Barton fault (Park 1989) (Fig. 4) range from 35.5 to $48.5 \mathrm{My}$. These ages are consistent with the K-Ar age of basaltic andesite, BPI2 $(45.9 \pm 3.8 \mathrm{My})$.

As mentioned above, all of the analysed specimens were slightly to moderately altered and/or experienced low-grade metamorphism. Nonetheless, the ${ }^{40} \mathrm{Ar} /{ }^{39} \mathrm{Ar}$ ages obtained in this study are 


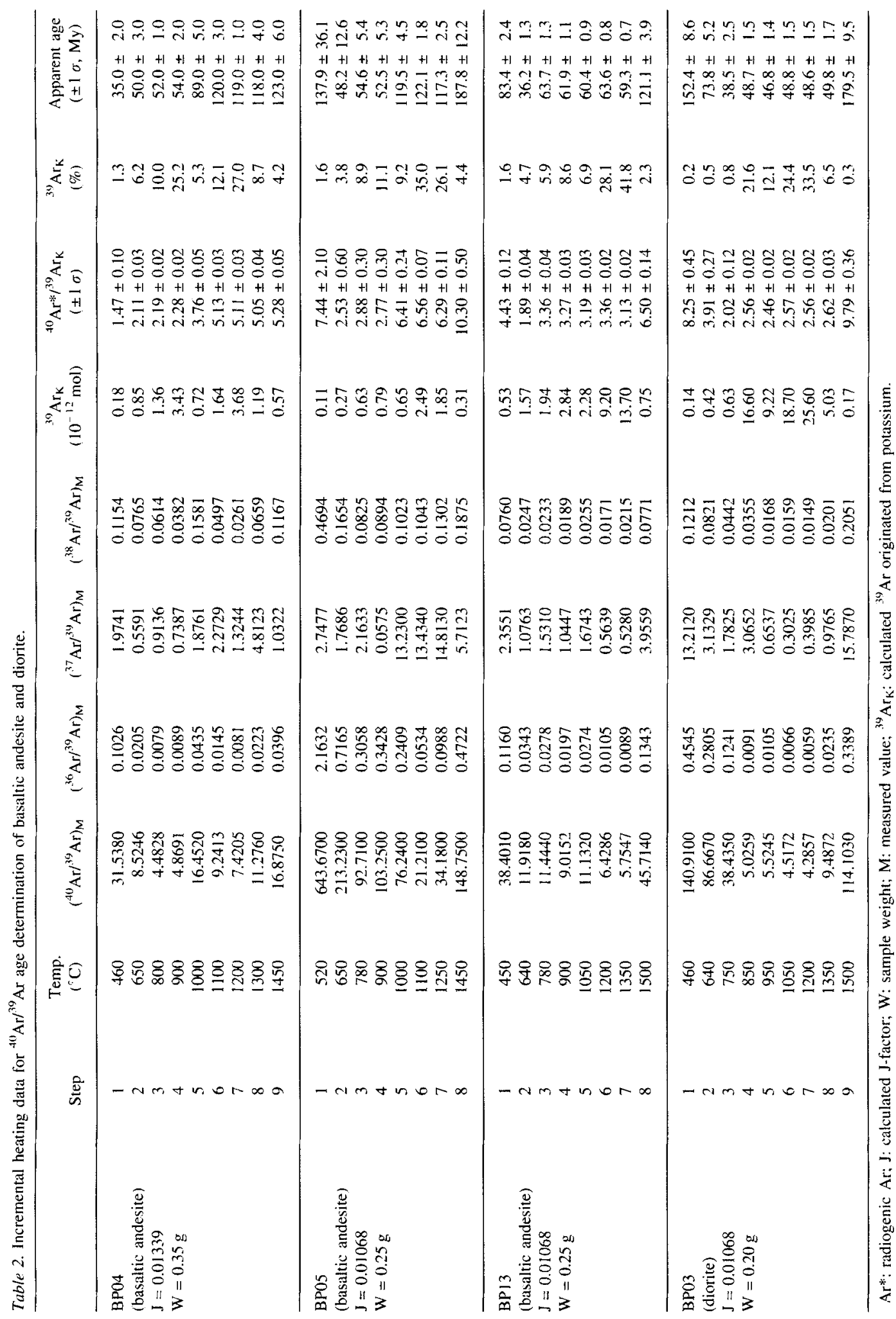



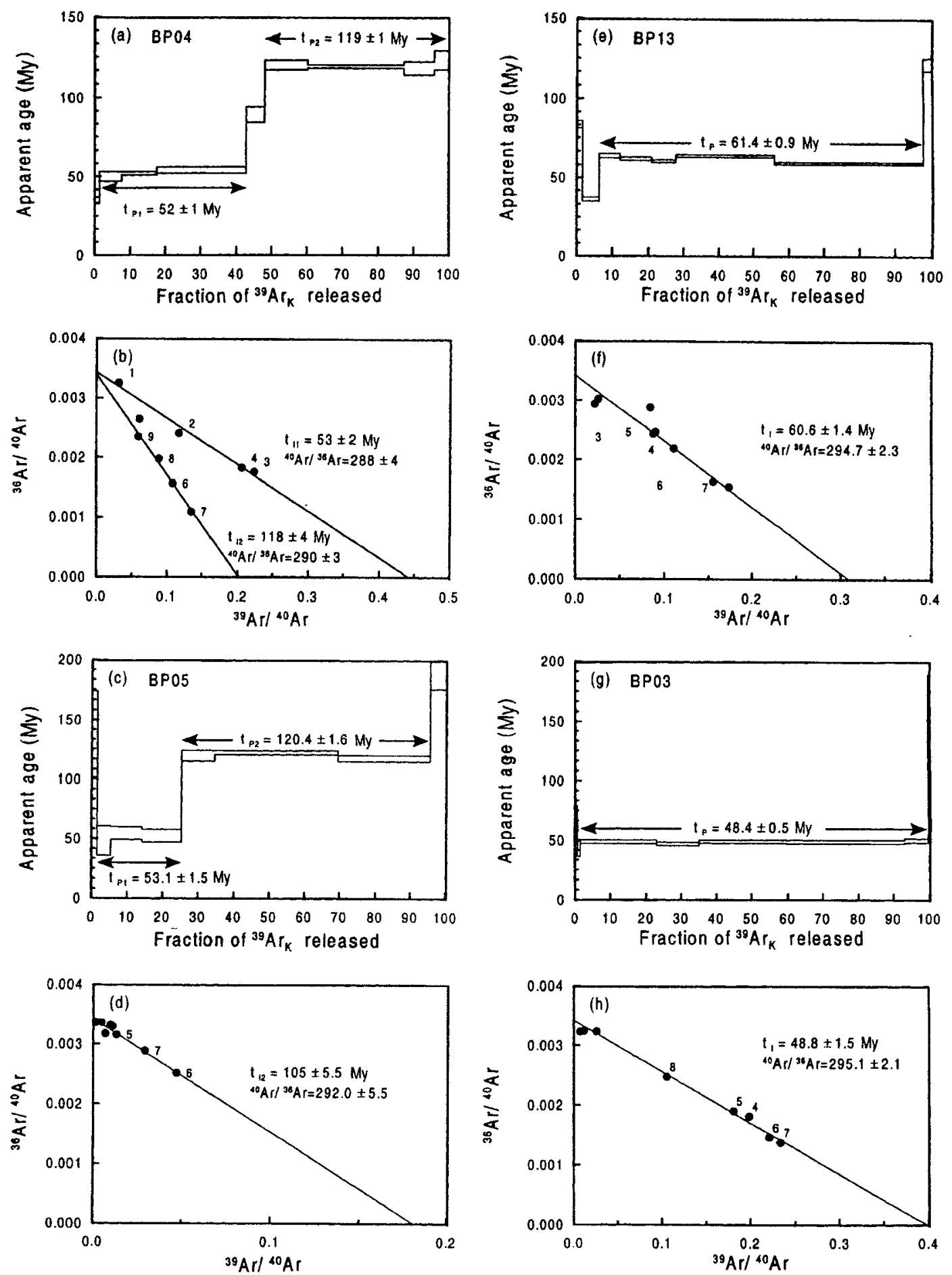

Fig. $3{ }^{419} \mathrm{Ar} /{ }^{39} \mathrm{Ar}$ apparent ages and isotope correlation diagrams of basaltic andesite and diorite from Barton Peninsula, King George Island. Antarctica. Abbreviations: $\mathrm{P}=$ apparent plateau ige; $\mathrm{I}=$ isochron age: 1 = low-temperature fractions; 2 = high-temperature fractions. $(\mathrm{a}-\mathrm{f})$ are for basaltic andesite, and $(\mathrm{g}-\mathrm{h})$ for diorite. 


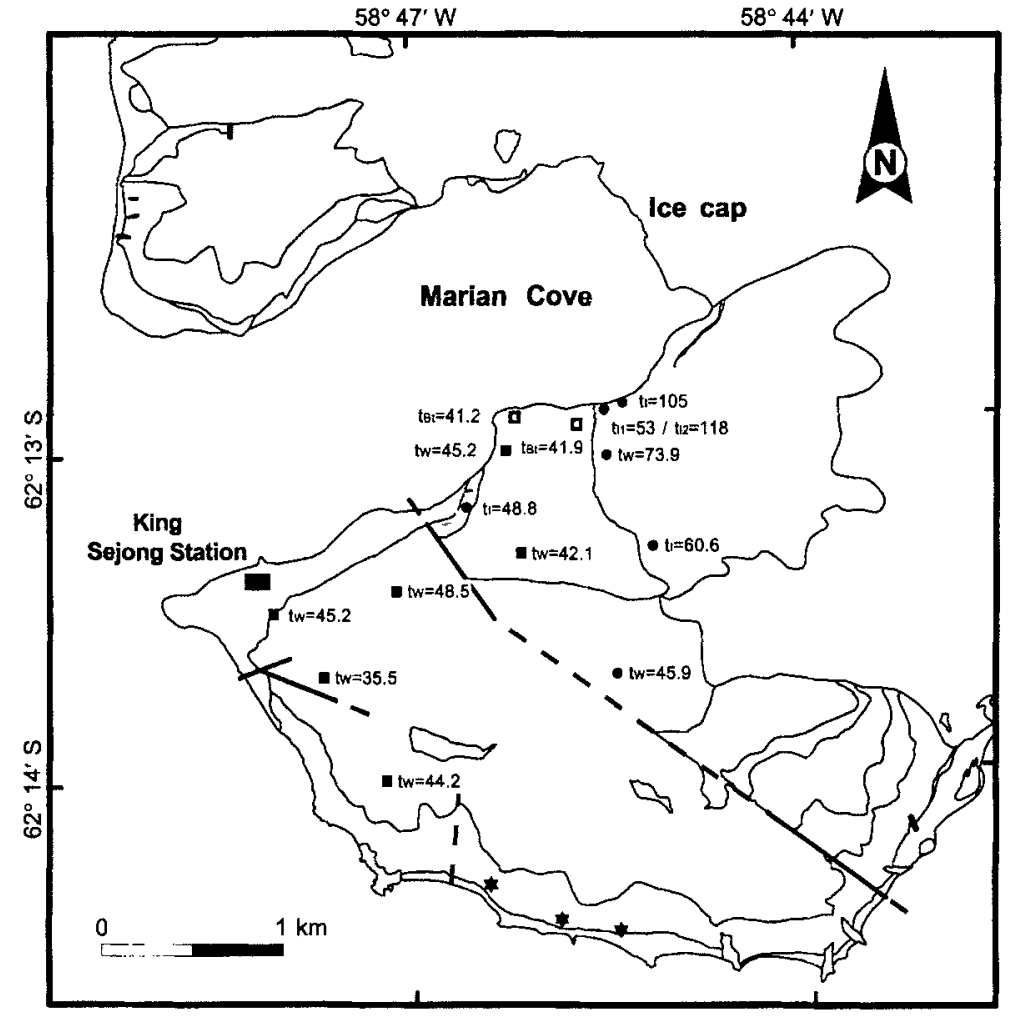

Fig. 4. Map showing the ${ }^{40} \mathrm{Ar} /{ }^{39} \mathrm{Ar}$ and $\mathrm{K}$-Ar ages compiled from this and previous studies of Barton Peninsula. King George Island. Filled circles represent the results of this study. Filled and open squares denote the results of Park (1989) and Lee et al. (1996), respectively. Filled stars refer to the locations of plant fossils reported by Chun et al. (1994). Abbreviations: $\mathrm{t}_{\mathrm{Bt}}=$ biotite age; $\mathrm{t}_{\mathrm{w}}=$ wholerock age; $t_{1}=$ isochron age; $t_{11}=$ low-temperature fraction isochron age; $t_{12}=$ high temperature fraction isochron age.

considered to be reliable because the initial ${ }^{40} \mathrm{Ar} /{ }^{36} \mathrm{Ar}$ ratios of analysed specimens are consistent with that of present atmospheric argon (295.5). Furthermore, the apparent plateau ages are compatible with isochron ages, which support this interpretation. The old isochron ages determined in this study thus suggest an Early Cretaceous volcanic activity on Barton Peninsula, whereas the young ages are compatible with the Eocene ages previously determined from the plutonic rocks. Thus, the latter are interpreted to be the ages reset by the thermal effect during the emplacement of plutons.

Plant fossils of late Palaeocene to early Oligocene ages occur in reddish to black shales intercalated with agglomerates in the southern part of Barton Peninsula (Fig. 4) (Del Valle et al. 1984; Chun et al. 1994). These results are incompatible with the $\mathrm{K}$ - $\mathrm{Ar}$ and ${ }^{40} \mathrm{Ar} /{ }^{39} \mathrm{Ar}$ ages determined by this study, as well as with the previous suggestion of a Mesozoic age of volcanic rocks on the Barton Peninsula (Davies 1982; Birkenmajer, Narebski et al. 1983b). On the other hand, Tokarski et al. (1987) suggested a possible presence of Mesozoic volcanic rocks on Barton Peninsula. Furthermore, plant fossils documented from the Jurassic strata of Hope Bay, Antarctic Peninsula, are also reported from the Cardozo Cove Group of the Barton Horst (Zastawniak 1981; Birkenmajer \& Zastawniak 1986). The Cardozo Cove Group of the Admiralty Bay (Fig. 1c) is correlated with the volcanic sequence of Barton Peninsula (Birkenmajer 1982). Thus, we cannot preclude the occurrence of Mesozoic volcanic and volcaniclastic rocks on Barton Peninsula.

Based on the similarity of K-Ar ages, Jwa et al. (1992) suggested that the displacement of the Barton Horst with respect to the Fildes Block is negligible. $\mathrm{K}$-Ar and ${ }^{40} \mathrm{Ar} /{ }^{39} \mathrm{Ar}$ ages from the eastern part of pluton, however, indicate the presence of Early to Late Cretaceous volcanism on Barton Peninsula and do not coincide with an age of 40-60 My for the Fildes Block. The agglomerate, the lowermost volcanic unit of southern Barton Peninsula, contains Eocene flora fossils but is absent in the northwestern peninsula across the Barton fault. On the other hand, lapilli tuff abruptly diminishes in its occurrence to the south of the Barton fault. 
The apparent discrepancies in geologic and geochronologic data across the Barton fault can be accounted for by the presence of significant displacement across the fault. This fault is thought to be a transform fault which is related to the opening of the Bransfield Strait. Previously determined $\mathrm{K}-\mathrm{Ar}$ ages from the volcanic rocks of the southern part of Barton Peninsula (Park 1989) are well correlated with Eocene volcanism having widely occurred in the Fildes and the Warszawa blocks of King George Island.

$\mathrm{Hu}$, Zheng et al. (1996) reported Late Cretaceous to late Eocene $(92-40 \mathrm{Mya}){ }^{40} \mathrm{Ar} /{ }^{39} \mathrm{Ar}$ and $\mathrm{K}$ $\mathrm{Ar}$ ages in the northern Fildes Block of King George Island. These ages successively decrease toward the north-east, and Hu, Zheng et al. (1996) have attributed this systematic change to the gradual migration of the volcanic centre (Pankhurst \& Smellie 1983; Smellie, Pankhurst et al. 1984). Our result, however, indicates a large temporal gap along a vertical set of volcanic sequences in a narrow area. Furthermore, recent geochronologic studies on Livingston Island indicate an Early to Late Cretaceous (137$73 \mathrm{Mya}$ ) volcanic activity (Smellie, Pallàs et al. 1996; Zheng, Hu et al. 1997; Zheng, Sang et al. 1998) corroborating our result. It is thus likely that at least parts of King George and Livingston islands are composed of Early Cretaceous volcanic sequences.

\section{Conclusions}

1) ${ }^{40} \mathrm{Ar} /{ }^{39} \mathrm{Ar}$ step-heating whole-rock ages determination of basaltic andesite from Barton Peninsula in King George Island suggest two separate magmatic activities: Early Cretaceous and middle Eocene.

2) ${ }^{40} \mathrm{Ar} /{ }^{39} \mathrm{Ar}$ and $\mathrm{K}-\mathrm{Ar}$ ages of volcanic rocks in the northern pluton part are compatible with the stratigraphic relationship among sedimentary and volcaniclastic sequences. In spite of thermal resetting caused by the intrusion of pluton, ${ }^{40} \mathrm{Ar} /{ }^{39} \mathrm{Ar}$ step-heating ages of basaltic andesite preserve the evidence for Early Cretaceous volcanic activity in the northern Barton Peninsula.

3) Geologic and geochronologic differences across the north-west-south-east trending fault indicate the presence of tectonic discontinuity on Barton Peninsula.
Acknowledgements. - This work was financially supported by the Ministry of Maritime Aftairs and Fisheries, South Korea, through KORDI (PP98001 04), and by the Nature Science Foundation of China (49672107), the Chinese Academy of Sciences (KZ951-A1-205-02) and the Ministry of Science and Technology, China (98-927-01-06-05).

\section{References}

Arche, A., López-Martinez, J. \& Martínez de Pison, E. 1992: Sedimentology of the Miers Bluff Formation, Livingston Island, South Shetland Islands. In Y. Yoshida et al. (eds.): Recent progress in Antarctic earth science. Pp. 357-362. Tokyo: Terra Scientific Publishing.

Barton, C. M. (ed.) 1965: The geology of the South Shetland Islands: III. The stratigraphy of King George Island. Br. Antarct. Surv. Sci. Rep. 44.

Birkenmajer. K. 1980a: Tertiary volcanic-sedimentary succession at Admiralty Bay, King George Island (South Shetland Island, Antarctica). Stud. Geol. Pol. 64, 7-65.

Birkenmajer, K. 1980b: Report on geological investigations of King George Island, South Shetland Islands (West Antarctica), in 1978-1979. Stud. Geol. Polon. 64, 89-105.

Birkenmajer, K. 1980c: A revised lithostratigraphic standard for the Tertiary of King George Island, South Shetland Islands (West Antarctica). Bull. Pol. Acad. Sci., Eurth Sci. 27(1/2), $49-57$.

Birkenmajer, K. 1980d: Geology of Admiralty Bay, King George Island (South Shetland Islands) - an outline. Pol. Polar Re's. 1(1), 29-54.

Birkenmajer, K. 1982: Mesozoic stratiform volcanic-sedimentary succession and Andean intrusions at Admiralty Bay, King George Island (South Shetland Islands, Antarctica). Stud. Geol. Pol. 74(3). 105-154.

Birkenmajer, K. 1983: Late Cenozoic phases of block-faulting on King George Island, South Shetland Islands, West Antarctica. Bull. Pol. Acad. Sci., Earth Sci. 30(1/2), 21-32.

Birkenmajer, K. 1989: A guide to Tertiary geochronology of King George Island, West Antarctica. Pol. Polar Res. 10(4), $555-579$.

Birkenmajer. K., Francalanci, L. \& Peccerillo, A. 1991: Petrological and geochemical constraints on the genesis of Mesozoic-Cenozoic magmatism of King George Island, South Shetland Islands, Antarctica. Antarct. Sci. 3(3), 293308.

Birkenmajer, K., Narebski, W., Nicoletti. M. \& Petrucciani. C. 1983a: Late Cretaceous through late Oligocene K-Ar ages of the King George Island Supergroup volcanics, South Shetland Islands (West Antarctica). Bull. Pol. Acad. Sci., Earth Sci. 30(3/4), 133-143.

Birkenmajer K., Narebski, W.. Nicoletti, M. \& Petrucciani, C. 1983b: K-Ar ages of the "Jurassic volcanics" and "Andean" intrusions of King George Island. South Shetland Islands (West Antarctica). Bull. Pol. Acad. Sci., Earth Sci. 30(3/4). $121-131$.

Birkenmajer. K. \& Zastawniak. E. 1986: Plant remains from the Dufayel Island Group (early Tertiary?), King George Island. South Shetland Islands (West Antarctica). Acta Pulaeobot. Pol. 26(1/2), 33-54.

Chun, H. Y., Chang. S. G. \& Lee, J. I. 1994: Biostratigraphic study on the plant fossils from the Barton Peninsula and adjacent areas. J. Paleontol. Soc. Korea $10(1), 69-84$. 
Davies, R. E. S. 1982: The geology of the Marian Cove area, King George Island and Tertiary age for its supposed Jurassic volcanic rocks. Br. Antarct. Surv. Bull. 51, 151-166.

Del Valle, R. A., Diaz, M. T. \& Romero. E. J. 1984: Preliminary report on the sedimentites of Barton Peninsula, 25 de Mayo Island (King George Island), South Shetland Islands. Argentine Antarctica. Contrib. Inst. Antárt. Argent. 308, 119.

Ferguson, D. 1921: Geological observations in the South Shetland Islands, the Palmer Archipelago and Graham Land. Antarctica. Trans. R. Soc. Edinburgh 53(1), 29-55.

Hathway, B. \& Lomas, S. A. 1998: The Upper Jurassic-Lower Cretaceous Byers Group, South Shetland Islands, Antarctica: revised stratigraphy and regional correlations. Cretac. Res. $19,43-67$.

Hu. S. L., Wang, S. S.. Sang, H. Q. \& Qiu, J. 1985: An application of the fast-neutron activation dating technique to approach the age of early emplacement of Jiuling granodiorite intrusion of Jiangxi province. Acta Petrolog. Sin. I, 29-34.

Hu, S. L., Zheng, X., Molan, E. \& Birkenmajer. K. 1996: ${ }^{411} \mathrm{Ar} /{ }^{39} \mathrm{Ar}$ and $\mathrm{K}$-Ar age datings on the volcanic rocks in northern coast of King George Island, West Antarctica. Korean J. Polar Res. 7(1), 11-21.

Jwa. Y.-J., Park, B.-K. \& Kim, Y. 1992: Geochronology and geochemistry of the igneous rocks from Barton and Fildes peninsulas, King George Island: a review. In Y. Yoshida et al. (eds.): Recent progress in Antarctic earth science. Pp. 439 442. Tokyo: Terra Scientific Publishing.

Kang. P.-C. \& Jin, M.-S. 1989: Petrology and geologic structures of the Barton Peninsula. King George Island, Antarctica. In H. T. Huh et al. (eds.): Antarctic science: geology and biology. Pp. 121-135. Seoul: Korea Ocean Research and Development Institute.

Kawashita, K. \& Soliani, E., Jr. 1988: A Rb-Sr isochron diagram for the Znosko Glacier Formation (Cardozo Cove Group), Admiralty Bay, King George Island, Antarctica. Ser. Cient. Inst. Antârt. Chil. 38, 59-66.

Kim, H.. Cho, M. \& Lee, J. I. 1995: Low-pressure thermal metamorphism of volcanic rocks in the Barton Peninsula, King George Island. Antarctica. In Y. Kim et al. (eds.): The fourth Seoul International Symposium on Antarctic Science Geology of the South Shetland Islands. Pp. 25-27. Seoul: Korea Ocean Research and Development Institute.

Kim, H., Cho, M. \& Lee, J. I. 2000 (unpubl. ms.): Thermal metamorphism of volcanic rocks in the Barton Peninsula, King George Island, Antarctica.

Lee, J.-I., Hwang, J., Kim, H., Kang, C. Y., Lee, M. J. \& Nagao, K. 1996: Subvolcanic zoned granitic pluton in the Barton and Weaver peninsulas, King George Island. Antarctica. In K. Moriwaki et al. (eds.): Proceedings of the 15th NIPR Symposium on Antarctic Geosciences. Pp. 76-90. Tokyo: National Institute of Polar Research.
Pankhurst, R. J. \& Smellie, J. L. 1983: K-Ar geochronology of the South Shetland Islands, Lesser Antarctica: apparent lateral migration of Jurassic to Quaternary island arc volcanism. Earth Planet. Sci. Letl. 66, 214-222.

Park, B.-K. 1989: K-Ar radiometric ages of volcanic and plutonic rocks from the Barton Peninsula, King George Island, Antarctica. J. Geol. Soc. Korea 25(4), 495-497.

Smellie, J. L., Liesa. M., Muñoz, J. A., Sàbat, F., Pallàs, R. \& Willan, R. C. R. 1995: Lithostratigraphy of volcanic and sedimentary sequences in central Livingston Island, South Shetland Islands. Antarct. Sci. 7(1), 99-113.

Smellie, J. L.. Pallàs, R.. Sàbat. F. \& Zheng, X. S. 1996: Age and correlation of volcanism in central Livingston Island, South Shetland Islands: K-Ar geochemical constraints. J. South Amer. Earth Sci. 9(3/4), 265-272.

Smellie, J. L., Pankhurst, R. J., Thomson, M. R. A. \& Davies, R. E. S. (eds.) 1984: The geology of the South Shetland lslands: VI. Stratigraphy, geochemistry and evolution. Br. Antarct. Sur: Sci. Rep. 87.

So, C.-S., Yun, S.-T. \& Park, M.-E. 1995: Geochemistry of a fossil hydrothermal system at Barton Peninsula, King George Island. Antarct. Sci. 7, 63-72.

Steiger, R. H. \& Jäger, E. 1977: Subcommission on geochronology convention on the use of decay constants in geo- and cosmochronology. Earth Planet. Sci. Lett. 36, 359-362.

Tokarski, A. K. 1988: Structural analysis of Barton Peninsula (King George Island, West Antarctica): an example of volcanic are tectonics. Stud. Geol. Pol. 95, 53-63.

Tokarski. A. K., Danowski, W. \& Zastawniak. E. 1987: On the age of fossil flora from Barton Peninsula, King George Island, West Antarctica. Pol. Polar Res. 8(3), 293-302.

Tyrrell. G. W. 1921: A contribution to the petrography of the South Shetland Islands, the Palmer Archipelago and the Danco Land Coast, Graham Land, Antaretica. Trans. R. Soc. Edinburgh 53, 57-79.

Willan, R. C. R., Pankhurst, R. J. \& Hervé, F. 1994: A probable Early Triassic age for the Miers Bluff Formation, Livingston Island, South Shetland Islands. Arctarct. Sci, 6, 401-408.

York, D. 1969: Least-squares fitting of a straight line with correlated errors. Earth Planet. Sci. Lett. 5, 320-324.

Zastawniak, E. 1981: Tertiary leaf flora from the Point Hennequin Group of King George Island (South Shetland Istands, Antarctica): preliminary report. Stud. Geolog. Pol. $72,97-108$.

Zheng, X. S., Hu, S. L., Liu, J. Q. \& Sabat, F. 1997: New ${ }^{40} \mathrm{Ar} /{ }^{39} \mathrm{Ar}$ age evidence for the Cretaceous volcanic rocks of the Mount Bowles Formation in Livingston Island, South Shetland Islands. Chin. J. Polar Sci. 8(2), 89-95.

Zheng, X. S., Sang, H. Q., Qiu, J., Liu, J. Q.. Lee, J.-I. \& Hwang, J. 1998: Isotopic age of the volcanic rock in Byers Peninsula, Livingston Island, West Antarctica. Chin. J. Polar Res. IO(l), $1-10$. 